\title{
POETYCKI TEATRZYK MAŁYCH FORM DRAMATYCZNYCH NA ŁAMACH „MUCHY” I „KOLCÓW” W LATACH SIEDEMDZIESIĄTYCH XIX WIEKU*
}

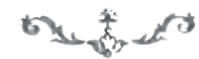

$\mathbf{R}_{\text {- korzertuar teatru CZasopism humorcego z nieograniczonych możliwości tworzywa słownego }}$ i pracy wyobraźni czytelnika - już u swego zarania w historii polskiej kultury (które przypada na początek lat siedemdziesiątych XIX wieku) przedstawia takie bogactwo form, konwencji, poetyk, że daje się porządkować wedle wielu kryteriów, przy czym właśnie ze względu na swą dopuszczalną mnogość nasuwające się kryteria tematyczne, genologiczne, formalne (wiersz-proza), estetyczne (realizm-karykatura-symbol-fantastyka-groteska) ustanawiają za każdym razem zbiory przykładów wzajemnie między sobą zróżnicowanych.

Banalny temat zalotów można by wyczerpać w symbolicznym skrócie, jakiego dostarczył „dramat” Julia i Adolf, przedstawiony w „Kolcach” z 1875 roku:

(Teatr wystawia salon - w głębi drzwi - po prawej stronie kanapa i parę krzeseł. Julia sama - ściera kurz z kanapy - stychać pukanie do drzwi - zbliża się i otwiera).

Adolf (wchodząc do salonu - kłania się). Pani!

Julia (wychodząc na środek sceny - z głębokim ukłonem). Panie! (po chwili spostrzegłszy, że nie ma sensu tak stać na środku sceny, zbliża się do kanapy i pokazuje na krzesto) Panie!

* Artykuł powstał $\mathrm{w}$ ramach realizacji grantu badawczego $\mathrm{nr} 11 \mathrm{H} 11$ 013880: Poezja na marginesie cywilizacji. Degradacja i odrodzenie twórczości poetyckiej w latach 1864-1894 (podstawa bibliograficzno-materiałowa), finansowanego ze środków Narodowego Programu Rozwoju Humanistyki. 
Adolf (usiada obok Julii). Pani! (wpatruje się w nią z coraz głębszym zajęciem upuszcza kapelusz i składa ręce) Pani!

Julia (zdziwiona). Panie! (spuszcza oczy i patrzy na koniec nosa).

Adolf (uniesiony wdziękami Julii pada przed nia na kolana). Pani!

Julia (oburzona wyskakuje na środek sceny). Panie!

Adolf (oburzony obojętnością Julii - z gorzkim wyrzutem). Pani! (wypada gwattownie za scenę).

Julia ( $w$ obawie o rozpacz Adolfa rzuca się ku drzwiom). Panie!

(Stychać tylko dudnienie po schodach uciekającego Adolfa - Julia pada na ziemie zemdlona). ${ }^{1}$

Konteksty, w jakich osadzano zbliżone tematycznie wierszowane scenki obyczajowe, dawały też czasami świadectwo zachodzącym w tej sferze procesom. Siostrzane dusze na przykład eksponowały aktywność panny w rywalizacji z własną matką o względy kandydata na męża. Wyrazem obyczajowych przemian stawał się w tym dialogu komiczny chwyt odwrócenia ról pokoleniowych - tym razem córka strofuje i poucza:

Mama

Ale co ja mam robić?

Córka

Nie mizdrzyć się samej, Ot! przyjąć zwykłą rolę kochającej mamy, Wybadać... spytać Waćka - a to tak... z ostrożna, Toć przecie umiejętnie wszystko zrobić można. Nie tak jak do tej chwili - co to... żal się Boże! Zdecydować się Wacław istotnie nie może. Kocha się niby we mnie - aliż tylko wchodzi, Mama mu zaraz sama wszystkie chwile słodzi. Kręci się, wierci przy nim, jak subretka płocha, Stąd odgadnąć nie może, która $\mathrm{z}$ nas go kocha, Jeśli zaś złapać męża, chce się mamie wielce To ja sama poradzę w takiej bagatelce. I odstąpię Augusta - stary on garbaty, Ale dorzeczny przecie i dosyć bogaty. ${ }^{2}$

W przypadkach zachowania tradycyjnego rozkładu ról - a taki został zapowiedziany już w tytule „szkicu komedii oryginalnej” Posłuszna córeczka - także i on ulegał modyfikacji wywołanej społecznymi nowinkami, w tym przypadku za pośrednictwem motywu stręczenia córki mężczyźnie jeszcze żonatemu, przy użyciu argumentacji, w której „emancypacja” rymuje się z wyrazem „separacja”:

1 [b.a.], Julia i Adolf. Dramat, „Kolce” 1875, nr 14, s. 108.

2 Ee., Siostrzane dusze (Scena w salonie), „Mucha” 1873, nr 78, s. 305. 


\author{
MAMA GUCI \\ [...] \\ Wiesz, nasz sąsiad pan Ignacy, \\ Z przebiegłości swej i pracy \\ Sporo grosza ma... \\ Przy tym mąż już trzeciej żony, \\ Człowiek bardzo doświadczony \\ Wiele świata zna. \\ GuCiA \\ [...] \\ U nas przecie zabroniony \\ Jest zbytek mieć, aż dwie żony, \\ Nie... to tylko żart - \\ Mama Guci (serio) \\ Nie, to projekt doskonały, \\ Myśli go moje wydały, \\ Worów złota wart. \\ Wszak uczy emancypacja, \\ Że istnieje separacja, \\ $\mathrm{W}$ razie kiedy zgon \\ Choć czekany, nie przychodzi, \\ Separacja życie słodzi \\ Tak mężów, jak żon. ${ }^{3}$
}

Wątki swatania czy wręcz małżeńskiego handlu były przedstawiane zresztą nie tylko w tradycyjnym wariancie „sprzedaży” młodej dziewczyny bogatemu starcowi. Akcja Dobranego małżeństwa z podtytułem Komedia (autentyczna) w trzech aktach przez Hipolita Pstragga rozgrywa się między często w tych utworach spotykanymi postaciami Jej i Jego („Onej” i „Onego”?), z tym że On ma tu lat 24, Ona - 67 i występuje z orszakiem synów, zięciów, córek, synowych, wnuków i wnuczek, a bezpośrednio przed ślubem, „w zakrystii kościoła”, dosłownie kupuje sobie młodego męża za gotówkę pod groźbą zerwania zaręczyn - dosadnie wyrażoną: „Nie żenię się na kredyt, niechaj pani płaci" ${ }^{4}$.

Dalej można by jeszcze wymieniać dramaty małżeńskie i rodzinne, zawodowe i społeczne, a także fantastyczne i parodyjne - przy czym stosując kryterium tematyczne, to ostatnie pojęcie należałoby zawęzić do parodii fa-

3 [b.a.], Posłuszna córeczka. Szkic komedii oryginalnej pp. Ktoś, Olek i S-ka, napisany tylko w jednym akcie, ale za to z Prologiem i Epilogiem, „Kolce” 1872, nr 7, s. 106.

4 [b.a.], Dobrane małżeństwo. Komedia (autentyczna) w trzech aktach przez Hipolita Pstraga, „Kolce” 1872, nr 8, s. 120. 
buł, konfliktów czy postaci znanych z historii literatury. Oczywiście wyselekcjonowane typy będą się wzajemnie przenikały.

Na przykład Hamlet z roku 1871 - w pięcioaktowej „takiej sobie tragedii” zmieszczonej na czterech kolumnach czasopisma, otwartej absurdalną sceną ucieczki jednakowo przestraszonych żołnierzy i duchów w przeciwne strony - swoją strategię udawanego szaleństwa realizuje, ukazując się Ofelii: „Z odkrytą głową i zbrukane wlokąc / U nóg pończochy, aż do kostek zwisłe" ${ }^{\text {, co }}$ u jego dramatycznych antagonistów wzbudza, o dziwo, nie konsternację, ale precyzyjnie ukierunkowane podejrzenia:

Poloniusz. Słuchajcie! - Hamletowi zwisły pończochy do kostek.

KRól i Królowa razem. Być nie może!

Poloniusz. Ofelka widziała.

KLAUdiusz kręcąc się na miejscu. To znak fatalny. (do żony) Może on się czego domyśla. (głośno) Poloniuszu - nie wiesz, co zacz on w stroju niedbałym?

Poloniusz. Zostawcie go z mą córą,

Ona weźmie w rękę książkę, aby

Samotności dać przystojną barwę. ${ }^{6}$

W scenie z Ofelią wychodzi na jaw, że Hamlet jest redaktorem czasopisma - bo tak monologuje:

(wychodzi naprzód i udaje, że nie widzi Ofelki)

Być głupim albo nie być; oto jest pytanie?

Co z dwojga korzystniejsze? czy wytrzymać

Znawców ciosy lub zniewagi,

Czy przeciw ogółowi jadem się uzbroić

I nakładem moim go pokonać?! Sprzedać

$Z$ tysiąc egzemplarzy - gdybym w tym marzeniu

Zrzucić mógł z siebie długi i tysiączne troski -

Przyrodni dział takich jak ja - to na Lesznie

Nie siedziałbym. Sprzedać - zreklamować,

Zreklamowawszy, zgarnąć - ta myśl już zachwyca!?

Zrozumiałe więc, że po kłótni z Ofelią o drobne, których ta nie miała, aby mu „zmienić”, poirytowany Hamlet podczas rozmowy z Królową kłuje ukrytego za kotarą Poloniusza piórem, brudząc go atramentem.

Współczesna komunikacja prasowa zagościła też w parodii czegoś, czego - zdawałoby się - nie sposób już sparodiować, a mianowicie romansowej far-

5 [b.a.], Hamlet. Taka sobie tragedia w kilkunastu obrazach i fotogramach, „Mucha” 1871 , nr 14, s. 75.

6 Tamże.

7 Tamże. 
sy „z wielkiego Bokacjusza, przełożonej przez Bokacjuszka”, drukowanej w 1871 roku w „Kolcach” pod tytułem W oczach męża ${ }^{8}$. Akcja jednoaktówki koncentruje się wokół wmówienia zazdrosnemu staremu mężowi, że obserwowany z gruszy widok żony w miłosnym uścisku z kochankiem jest złudzeniem wywołanym przez jakąś tajemniczą moc zaklętą w drzewie. Do rangi magicznego gestu ujarzmiającego cudowną moc drzewa urasta zerwanie owocu.

Parodia na łamach „Muchy” z 1872 roku przybrała formę epilogowego drugiego aktu dopisanego do ogłoszonej w „Kolcach” - wzmiankowanej wyżej - jednoaktówki:

(Dekoracja ta sama - Scena przedstawia ogród - po lewej stronie jeszcze nieścięte wysokie drzewo gruszkowe - przy nim siekiera - przy drzewie drabina, - na prawo na ławeczce darniowej całuja się i ściskaja strasznie Astolf z Matylda - Gaudenty siedzi na samym wierzchołku gruszki.)

\title{
SCENA I
}

Gaudenty, Matylda, Astolf. Gaudenty

I znów się całujecie!?.. Matyldo kochana!

MATYLDA

Kochanku!... to złudzenie - to fatamorgana! GAUDENTY

Nie mogę tego pojąć - powiadam wam szczerze!

Warto by takie cuda umieścić w „Kurierze”,

W „Tygodniku” lub „Kolcach”, w „Wieńcu” lub „Gazecie”.

AstolF

Kto zna trochę fizyki, mój panie - toć przecie

Wie, że takie mamidła, zwodnicze obrazy,

Przedstawiają się oczom w Saharze sto razy;

Widzi je, kto przepływa przez Śródziemne Morze.

(całuja się).

[...]

\section{SCENA II}

(Ciż sami i czterech zakapturzonych drabów - jeden z batem - dwóch chwyta Astolfa za kotnierz).

\author{
ASTOLF \\ Co to jest?!! \\ MATYLDA \\ To zasadzka!!... \\ GAudenty ( $z$ gruszki). \\ O co wam to chodzi?
}

8 [b.a.], W oczach męża. Komedia w jednym akcie wierszem z wielkiego Bokacjusza, przełożona przez Bokacjuszka, „Kolce” 1871, t. 2, z. 6, s. 193-212. 
Astolf (broniąc się drabowi).

To podstęp - to nikczemność! wiesz acan dobrodziej!

Ja zaraz kryminalnie będę skarżył pana!!

GAUDENTY

Co wam się znowu zdaje? to fatamorgana! -

$[\ldots]$

(Astolf szarpie się z drabami - nareszcie wyrywa się i ucieka - draby gonia go za scenę - Matylda przytrzymuje drabinę - Gaudenty schodzi - Matylda ścina siekiera gruszke).

\section{ZASŁONA SPADA ${ }^{9}$}

Parodystyczna wersja jednoaktówki (podpisana przez „Brata Łatę”) łączyła więc temat zdrady małżeńskiej z docinkiem pod adresem współczesnej prasy w poetyce trochę absurdalnej anty-sielanki z finałem antycypującym - dzięki wtargnięciu drabów - rozwiązania znane z późniejszych dramatów Witkacego, przyprawione tu jeszcze dodatkowo domieszką purnonsensu bliskiego estetyce Zielonej Gęsi Gałczyńskiego, widocznego w obrazie słabej kobiety, ścinającej szybko i skutecznie drzewo podczas opadania kurtyny.

Częściej uciekano się do prostszych zabiegów - typy społeczne i zawodowe (mniej lub bardziej zdeformowane) występowały wymiennie z galerią znaczących nazwisk ${ }^{10}$, a parodyjność formalną sygnalizowały podtytuły zawierające kwalifikację gatunkową - na przykład: „plan do tragedii w 4-ch

9 [b.a.], Akt drugi do komedii Bokacjuszka pod tytułem „W oczach męża”, wydrukowanej w 6-m nrze „Kolców” w d. 15 grud. 1871, dodany jako epilog przez Brata Łate, „Mucha" 1872 , nr 8, s. 31.

10 Przykładowo: student Pędziwiatrowski chroni się przed spłatą zaległych należności za świadczone usługi (m.in. obiady w restauracji pana Odgrzywalskiego) rzekomo w posiadłości swojej umierającej babki, ,jenerałowej Armatnickiej”, która na pewno zostawi mu ogromny majątek (Wakacje, „Mucha” 1873, nr 53); panowie Fajtłapowicz i Rzodkwiński w jadłodajni nasyłają na siebie wzajemnie swoich wierzycieli (U pani Piotrowej, „Mucha” 1873, nr 23); Żona-Literatka zaprasza na odczyt swojej „dramy w ośmiu aktach” elitę artystyczno-dziennikarską, którą tak anonsuje mężowi: „Sławny autor pan Bzik / Tak w rodzaju Kornelia Rassyna. / Pan Fujarski poeta-estetyk, / Pan Gorylski poprzednik Darwina, / [...] / Pan Pomidor literat komiczny. / Pan Bzurski redaktor dziennika” (Fotofero, Mąż literatki, „Mucha” 1872, nr 29); tytułowi „piękni literaci” w scenie jakoby operowej z „Kolców” to: Buldog („krytyk krytyków”), Zoilewicz i Satyrkowski („dwaj krytycy”), Gapax („literat”) i Petit („literacik”) (Ktoś [S. Lipiński?], Piękni literaci. Scena z opery ułożona z ulubionych motywów nieśmiertelnego Offenbacha, „Kolce” 1872, nr 6); Albonic, Białko, Całusik, Mamut i Don Karnawał LXVII to bohaterowie komedii, której akcja „dzieje się na księżycu, w posiadłościach Don Karnawału, nad brzegami Morza Słodyczy” (A. Kurcz [W. Sabowski], Krwawy kotylion. Komi-tragedia historyczna w 1 akcie z prologiem i epilogiem, „Kolce" 1872, nr 3). 
aktach” („Kolce” 1872, nr 16); „fragment z komedii nienapisanej” (Fotofero, Mąż literatki, „Mucha” 1872, nr 29); „omal nie tragiczny dramat, czyli inaczej dzieło sceniczne, z prologiem, aktami, a naturalnie i epilogiem” („Kolce” 1872, nr 20); „melodramat życiowy z gazem, dekoracją, z przyjaciółmi domu i sensem moralnym” (Frou-Frou, „Mucha” 1871, nr 10); „nie komedia - bo się na małżeństwie nie kończy; nie dramat - bo się od małżeństwa nie zaczyna, lecz nie farsa także - bo z natury przez dziurkę od klucza" (Korwin [W. Chełmiński], Skąpy dwa razy traci, „Kolce” 1872, nr 18).

Ta pozorna dezynwoltura nazewnicza nie miała nic wspólnego z romantyczną rewolucją w genologii, przeciwnie - strategia parodyjna stanowiła właśnie wyraz dążenia odwrotnego, dążenia do precyzji terminologicznej i genologicznego ładu. Zadeklarowana klasyfikacja gatunkowa wyraźnie zobowiązywała - widać po efektach, że obietnicy złożonej w podtytule należało dotrzymać, komponując rzeczywiście parodię wskazanego gatunku. W ten sposób gazetowy teatrzyk wskrzeszał konwencje unieważnione przez wielką literacką reformę sprzed kilku dziesięcioleci - podobnie miał niebawem postąpić teatrzyk paryskich kabaretów z projektami wielkich dziewiętnastowiecznych reformatorów sceny ${ }^{11}$. Z całą ostrością ta świadomie przestrzegana w czasopiśmie zasada występuje na tle innych, niekwalifikowanych genologicznie form.

Obok parodii komponowanych w zgodzie z gatunkowymi schematami, a więc układanych też $\mathrm{w}$ regularne dramaty - które ze względu na skrupulatnie wprowadzane wskazówki inscenizacyjne można by nazwać projekcjami spektakli dla teatru wyobraźni - występowały w humorystycznych periodykach formy dialogowe pozbawione gatunkowych kwalifikatorów, podziału na części składowe dramatu (akty i sceny) oraz didaskaliów.

Obie formy - dramatyczna i dialogowa - zostały zresztą wkrótce wyparte przez krótkie, kilkureplikowe dialogowe dowcipy, których wykonanie powierzano stałym figurom, niewyposażanym w cechy indywidualne ( $\mathrm{w}$ „Musze" byli to Pankracy, Bonifacy i Serwacy) ${ }^{12}$.

I prawdę mówiąc, do takich właśnie dowcipów zbliżały się swoją konstrukcją owe dialogi nieoznaczane gatunkowo i puste inscenizacyjnie. Oglądane zaś z tej perspektywy jawią się prototypami kabaretowych skeczów.

11 Zob. I. Kiec, Wyprzedaż teatru w ręce błazna i arlekina... czyli o kabarecie, Poznań 2001 (tu zwł. rozdz. Wielka Reforma Teatru w świecie karnawału).

12 Na przykład: „PANKRACY: Wiecie, że obecnie Warszawa przypomina mocno Egipt? / BONIFACY: A to skąd znowu? / PANKRACY: Najpierw, że co noc miewamy CIEMNOŚCI EGIPSKIE, a po wtóre, że na ulicach wznoszą się olbrzymie PIRAMIDY” („Mucha” 1875, nr 4). 
Porównanie wydaje się o tyle uprawnione, że jakkolwiek kabaret w formie zinstytucjonalizowanej powstał we Francji dopiero u progu lat osiemdziesiątych XIX wieku, a do Polski zawitał oficjalnie dwadzieścia lat później, to jednak pierwsze przejawy tej sztuki u nas - jeszcze nienazwanej i nieświadomej siebie - obserwuje się już w latach dwudziestych XIX wieku w warszawskich kawiarniach, tych zwłaszcza, które odwiedzał wzięty gawędziarz i kalamburzysta, znakomity komik i popularny improwizator teatru Wojciecha Bogusławskiego - Alojzy Żółkowski (ojciec), redaktor humorystycznego „Momusa” ${ }^{13}$.

Jeżeli „Momus” Żółkowskiego utrwalał treść i konwencję kawiarnianych występów swego redaktora za pomocą słowa pisanego ze skutkiem dość mizernym, to wina częściowo tylko leży po stronie trudności, jakie sprawia przekład sztuki aktorskiej na język gazety, częściowo zaś spada mimo wszystko na nieprzygotowanie tak samego języka, jak i warsztatu artystycznego. Wszakże za sprawą powiązania u samych początków kawiarnianego występu o charakterze kabaretowym $\mathrm{z}$ redagowaniem czasopisma postrzeganie prasy humorystycznej w kategoriach nie tylko szkoły późniejszego stylu kabaretowego, ale i kuźni właściwych tej sztuce form, wydaje się jakoś usprawiedliwione - i tym samym może uzasadniać odnajdywanie prototypów skeczu w dialogowych formach satyrycznych.

Dłuższe statyczne dialogi na łamach „Muchy” i „Kolców” lokalizowano w miejscach typowych i rozpoznawalnych jak: stancja, urząd, jadłodajnia, gabinet lekarski, przedział kolejowy. Zapowiadały tę konwencję nawet tytuły: W wagonie („Mucha” 1872, nr 12); Na Smólikowszczyźnie („Mucha” 1873, nr 24); Wakacje („Mucha” 1873, nr 53); Fotografie ze scen szpitalnych („Kolce” 1875, nr 15). Formy te nie miały zwartej akcji, którą kwestie dialogowe mogłyby napędzać - układ i kształt replik ukierunkowane były nie na działanie, lecz na efekt - i on też zdaje się jedynym kryterium delimitacji tekstu.

Sąsiedztwo zminiaturyzowanych form dramatycznych $z$ jednej strony i zdialogizowanych dowcipów z drugiej każe w takim dialogowym skeczu widzieć nie - jak chce Ryszard Marek Groński - „skondensowaną komedię" ${ }^{14}$, lecz przeciwnie: rozbudowany dowcip, w najlepszym zaś razie coś w rodzaju jednej komediowej sceny - i to sceny o charakterze komicznego (niejednokrotnie farsowego) intermedium, dla rozwoju akcji i dla całej komediowej konstrukcji bynajmniej nie najważniejszej. Komedia rozwija się

13 Zob. H. Karwacka, Warszawski kabaret artystyczno-literacki „Momus”, Warszawa 1982.

14 R.M. Groński, Jak w przedwojennym kabarecie. Kabaret warszawski 1918-1939, Warszawa 1978, s. 12. 
jednak od ekspozycji do rozwiązania konfliktu (jak tragedia do katastrofy), skecz natomiast i dowcip - od zawiązania sytuacji do pointy.

Toteż jak dramat nie jest związany z jedną z form wypowiedzi, tak i owe pra-skecze można wyłonić zarówno $z$ dialogów prozatorskich, jak i wierszowanych. Przynajmniej tych publikowanych w „Musze” i „Kolcach”. Przy lekturze poniższego przykładu - „nie-komedii” Skapy dwa razy traci - trzeba pamiętać, że o zasadę konstrukcyjną tu chodzi, a nie o uzyskany efekt komiczny:

ON (trzymając album w ręku, $z$ niechcenia wsparty na biurku, obok którego ONA siedzi rozparta w fotelu)

(platonicznie)

Nie, ja nie wierzę, nie wierzę jeszcze,

Aby twe oczy, te gwiazdy wieszcze,

Co mi ku dobru były podnietą,

Kłamały wówczas.

ONA uśmiechając się i przymrużając oczy.

Przestań poeto

[...]

W miłość nie wierzę,

Są wprawdzie w życiu człowieka chwile,

$\mathrm{W}$ których ubiera w farby motyle,

Ku większej jeszcze swych zmysłów męce

Wszystko - lecz wszystko to jest zwierzęce,

A więc znikome.

ON (chcac ja przekonać).

Tyś zapomniała

Chwili, wśród której dusza twa biała

Mogła na zawsze zostać splamioną!...

Gdym mógł swe usta tulić w twe łono,

Boś wówczas więcej nie miała siły

Tylko by szeptać: „kocham cię miły”.

Czcząc jednak wszystko, co święte w tobie,

Uszanowałem twą miłość w sobie,

Miłość tak świętą kto dziś okupi?!...

ONA (przerywajac).

A cóż ja winna, że byłeś... głup...

ON (widocznie przekonany, siada - następuje milczenie).

KONIEC $^{15}$

Częściej w formę wierszowaną przystrajano „skecze” obyczajowe (Preferans we dwoje. Obrazek salonowo-dramatyczny, „Mucha” 1873, nr 87; cyto-

15 Korwin [W. Chełmiński], Skapy dwa razy traci. Nie komedia - bo się na małżeństwie nie kończy; nie dramat - bo się od małżeństwa nie zaczyna, lecz nie farsa także - bo $z$ natury przez dziurkę od klucza, podstuchat Korwin, „Kolce” 1872, nr 18, s. 63. 
wane Siostrzane dusze, „Mucha” 1873, nr 78; Fotofero, Knajpiarze, „Kolce” $1875, \mathrm{nr} 31$ ), ale zdarzały się próby przyswojenia formie wierszowanej tematyki skrajnie niepoetyckiej, jak w przypadku podpisanej przez Józefa Puszkowskiego Rozmówki na bruku warszawskim („Kolce” 1872, nr 35) w serii „Klejnoty humoru polskiego”, gdzie tasiemcowy dialog o spekulacjach głównie raził formalnym anachronizmem.

Paradoksalnie ślady nowatorstwa noszą raczej parodie gatunków dramatycznych - te wszystkie dramaty „planowane”, „nienapisane”, wieloprzymiotnikowe i oksymoronicznie określane, czyli formy jakoś zanurzone w tradycji literackiej i teatralnej.

Rzecz nie byłaby szczególnie zaskakująca przy świadomości, że konwencja kabaretowa formowała się w opozycji do pomysłów reformatorów teatru z końca XIX wieku - zwłaszcza wobec zasady „czwartej ściany”, obowiązującej w naturalistycznym teatrze André Antoine'a ${ }^{16}$ - gdyby nie fakt, że reforma była jeszcze w powijakach, gdy teatrzyki „Muchy” i „Kolców” zaczęły burzyć „czwartą ścianę”, ustanowioną przez francuskiego reżysera na dobre dopiero pod koniec lat osiemdziesiątych.

Tymczasem na łamach „Muchy” już w 1875 roku Gracz, czyli Dziecię stawione na kartę. Dramat w 8-miu obrazach rozgrywał się w dialogu przebiegającym pomiędzy Sceną, Publicznością i Krytyką:

\section{OBRAZ PIERWSZY}

SCENA

Fryderyk zgrał się w karty i nie ma pieniędzy,

A jego żona $\mathrm{z}$ dzieckiem są w okropnej nędzy.

Publiczność

Brawo! ja lubię zawsze słyszeć jęk rozpaczy.

KRYTYKA

W konsekwentnym następstwie to los wszystkich graczy.

\section{OBRAZ DRUGI}

SCENA

Baron, stryj Fryderyka jest głupi jak owca,

I zamiast wyrwać z błota biednego synowca

Przez namowę szczwanego swego sekretarza,

Chce adoptować osła, co się często zdarza.

PuBliczNość

Pan baron postępuje arystokratycznie...

KRYTYKA

Dotychczas rzecz rozwija się psychologicznie. ${ }^{17}$

16 Zob. I. Kiec, dz. cyt.

17 [b.a.], Gracz, czyli Dziecię stawione na kartę. Dramat w 8-miu obrazach, „Mucha” 1875 , nr 28 , s. 2 . 
Opublikowany w „Kolcach” z 1872 roku Plan do tragedii w 4ch aktach, ułożony przez pewnego młodego poetę [...] przewiduje w didaskaliach zachowania publiczności (tradycyjnie ten wynalazek w powiązaniu $\mathrm{z}$ inspiracją kabaretową przypisuje się dopiero Bertoltowi Brechtowi ${ }^{18}$ ): po pierwszym akcie, który wypełnia „rozmowa między hrabią a nim samym, czyli między jego Miłością a Rozsądkiem” (fragmenty tej rozmowy są w Planie zacytowane), „Kurtyna zapada, a publiczność z niecierpliwością oczekuje aktu drugiego, tymczasem zaś kobiety zostają w lożach, a mężczyźni idą do bufetu i piją poncz, orszadę, lemoniadę i co się komu podoba)" ${ }^{19}$.

Drukowany w tym samym piśmie kilka numerów dalej Galimatias, czyli Chaos, czyli Kobiety z kamienia już w podtytule podawał do wiadomości, że rozgrywać się będzie "na scenie, przed i za sceną" ${ }^{20}$. Postaci przyporządkowane w didaskaliach wstępnych poszczególnym przestrzeniom, w części dialogowej nie przestrzegają wytyczonych granic - literaci-recenzenci wchodzą „za kulisy”, a aktorka Julia pożycza rekwizyty (binokle i zegarek) od jednego z „wybrańców publiczności”, którzy nie są w spisie osób zaliczeni do grona aktorów. Ponadto dialogi „przed sceną” przenikają się z rozmowami „na scenie” i „za sceną”, a czasem odnosi się wrażenie, że wędrują między przestrzeniami same kwestie dialogowe - w samym tylko Prologu jedna wybrzmiewa „przy kasie”, druga „w ogrodzie”, inna „za sceną”. „Zasłona” kilka razy „podnosi się” i „spada”, a czasem „spada”, mimo że przed chwilą została opuszczona, zaś gdy mają odezwać się „głosy spoza zasłony”, nie wiadomo dokładnie, z której jej strony, przy czym według didaskaliów - dochodzą one „spoza zasłony” podniesionej ${ }^{21}$. Sensu w tym nie ma żadnego może poza znaczącym gestem nie tylko usunięcia „czwartej ściany”, ale pełnego unieważnienia ramy scenicznej i jeszcze otwarcia przestrzeni zakulisowej, co wkrótce stało się istotą kabaretowej „reformy na opak” 22.

Obok zaproszenia za kulisy gazetowy teatrzyk odsłaniał tajniki warsztatu dramatopisarskiego. Po występie Chóru Drzew, Chóru Słowików i Chó-

Zob. m.in. Historia teatru, red. J.R. Brown, przeł. H. Baltyn-Karpińska, Warszawa 1999, s. 404-405; L. Appignanesi, Kabaret, przeł. A. Kreczmar, Warszawa 1990, s. $151-152$.

19 [b.a.], Plan do tragedii w 4ch aktach, ułożony przez pewnego młodego poetę [...], „Kolce" 1872 , nr 16, s. 45.

Galimatias, czyli Chaos, czyli Kobiety z kamienia. Na scenie, przed i za scena. W Alhambrze. Omal nie tragiczny dramat, czyli inaczej dzieło sceniczne. Z prologiem aktami, a naturalnie i epilogiem. Stenografował Walet pikowy, „Kolce” 1872, nr 20, s. 87. Jw., s. $87-88$.

22 Zob. I. Kiec, dz. cyt., s. 48 i n. 
ru Ławek w Odgłosach z Saskiego Ogrodu tekst poboczny wprowadza w sferę autotematyzmu:

Mógłby tu jeszcze autor wprowadzić wiele innych chórów, jak: chór kwiatów, chór trawy, chór posągów, chór psów szczekających za ogrodem, chór dubeltówek w strzelnicy i tym podobnych chórów, wykonywanych przez istoty niemówiące, a tym bardziej i nieśpiewające, ale pozostawia to więcej kwiecistym i bujniejszą wyobraźnią obdarzonym poetom. ${ }^{23}$

Tekst poboczny pełnił funkcję narratora, a nawet - powiedzmy wprost - konferansjera, gdy w Zemście owadu z „Kolców”, oznaczonej jako Niby opera, niby balet fantastyczny w 3 aktach, w 5 obrazach, wystąpił w roli pośrednika między ludźmi teatru (aktorami, muzykami, tancerzami, śpiewakami i obsługą sceny) a publicznością:

\section{OBJAŚNIENIA}

DLA BALETNIC. Ubiory zupełnie przezroczyste, staniczków żadnych, oczkami czarować płeć brzydką w krzesłach, a szczególniej w dwóch pierwszych rzędach siedzącą, w razie nieposiadania prawdziwych brylantów używać imitacji ze szkła, byle się tylko świeciły - co do innych szczegółów, to urządzenie ich zostawia się własnemu uznaniu lub potrzebie.

Dla ChóRzystów. Nie brać Ut dolnego za As górne, nie robić własnych dodatków - nie spóźniać się i nie ucinać gapeusza na pulchne łydki baletniczek, bo one są watowane.

Dla ORKIESTRY. Muzykanci mają być spokojni - nie powinni unosić się, nie kręcić, nie wspinać, a nade wszystko nie patrzeć do góry, bo blask światła odbijającego się od wdzięków nadobnych tancerek jest nadzwyczaj szkodliwym... dla dokładnego wykonania partytury, a blansz i róż opadający z góry psuje wzrok, dlatego nawet winni nosić umbrelki i zielone okulary.

DLA MASZyNisty. Z urządzeniem maszynerii, fajerwerków, dekoracji i tym podobnych figielków nie spieszyć się, bo co nagle to po diable - zresztą komu pilno, to niech nie chodzi na baleta fantastyczne.

DLA widzów. Zabrania się używania lornetek, binokli, okularów i tym podobnych szkieł, gdyż wszystko będzie należycie i przy należytym świetle uwydatnionym tak dla krzeseł, jak i paradyzu. Przy tym zabrania się wszelkich uwag tyczących się fantazji w baletach fantastycznych. W razie pożaru młodzież z paradyzu i galerii chłodzić się może wodą „de wodociągibus”, młodzież zaś z krzeseł lodami i limoniadą, a w ostatku szampotkiem u Boucqueta. ${ }^{24}$

Powyższego przeglądu małych form dramatycznych na łamach „Muchy” i „Kolców” w latach siedemdziesiątych XIX wieku nie sposób zakończyć ina-

23 [b.a.], Odgłosy z Saskiego Ogrodu, „Kolce” 1872, nr 9, s. 134.

24 Pi-o-run [K. Krajewski?], Zemsta owadu. Niby opera, niby balet fantastyczny w 3 aktach, w 5 obrazach, „Kolce” 1872, nr 3, s. 40. 
czej, jak tylko cytatem, który wprawdzie genetycznie zanurzony jest w innym dziale redakcyjnej twórczości parateatralnej - konkretnie w serii ilustrowanych przeglądów teatralnych, wprowadzonych na łamy „Muchy” w 1875 roku - ale z dzisiejszej perspektywy efektownie zbliża się do kabaretowej konwencji gazetowego teatrzyku. Ów wynalazek sprawozdawczej ekfrazy - recenzja z ilustracją - zapowiedziany bowiem został w „Musze” w sposób, jakiego kilkadziesiąt lat później nie powstydziłby się chyba sam Fryderyk Járosy. Legendarny konferansjer międzywojennego Qui Pro Quo stosował, jak wiadomo, strategię obrażania zapowiadanych artystów i krytykowania własnego teatru - na przykład tak:

Niedawno w jednym z większych teatrów warszawskich rozległ się podczas przedstawienia głos: „Panie, niech pan tak głośno nie chrapie! Całą publiczność pan obudzi!" U nas taka solidarna śpiączka byłaby niemożliwą: Orkiestra przeszkadza!

To wielki minus naszego teatru, który zasadniczo ma dwa wielkie felery: pierwszy - że nie ma w nim w ogóle dobrych miejsc, bo orkiestrę wszędzie słychać, i drugie, że na siedemnaście numerów programu jest tylko sześć zapasowych wyjść. Natomiast wielkim plusem teatru Qui Pro Quo jest to, że większość aktorów ma złą dykcję. W ten sposób publiczność, mimo najszczerszych chęci, nie rozumie przeważnie tego, co aktorzy mówią, i dlatego nie wygwizduje programu. ${ }^{25}$

Tymczasem w zapowiedzi sprawozdania z przedstawienia Intrygi i miłości Friedricha Schillera w „Musze” z 1875 roku czytamy:

Każde pismo dobrze wychowane ma przynajmniej jednego sprawozdawcę teatralnego. „Mucha” posiada dwóch, którzy razem złączeni stanowią jedno. „Mucha” nie może się odwracać tyłem od prawd ekonomicznych. „Mucha” uwielbia korzyści wynikające z podziału pracy. „Mucha” byłaby zdolną bez przygotowania wygłosić prelekcję o stowarzyszeniach.

Jest jeden szkopuł, o który rozbijały się dotąd spółki literackie. Różność poglądów. Myśmy i to usunęli. Nasze zjednoczenie krytyków stanowi doskonałość w swoim rodzaju. Utwór grany na scenie powinien być widzianym i słyszanym. Jeden krytyk spełniający to podwójne zadanie, za nadto męczy oba zmysły i nie może być dokładnym. My posiadamy innego od widzenia, innego od słyszenia.

Jeden jest głuchy, drugi ślepy. Korzyści tego systemu uwydatnią się w następnym sprawozdaniu. ${ }^{26}$

Opis tych korzyści i komentarz do niego może „uwydatni się” w innym artykule.

Cyt. za: I. Kiec, Historia polskiego kabaretu, Poznań 2014, s. 88.

[b.a.], ,Intryga i miłość”, „Mucha” 1875, nr 12, s. [4]. 


\section{eretis \\ Marek Dybizbański (University of Opole) \\ e-mail: marek.dybizbanski@uni.opole.pl

\author{
Poetic Theater of Small Dramatic Forms \\ on the Pages of "Mucha” and "Kolce” In the 1870 S
}

\section{A B S T R A C T}

The repertoire of humorous periodicals, even at its early inception, allows to be organized according to numerous criteria - thematic, genealogical, formal and aesthetic ones. One can distinguish marriage and family, professional and social, fantastic and parody dramas. The selected types penetrate each other. Formal parody was signaled by subtitles containing the qualification that determined the formal shape of the work. In this way the newspaper theater revived the conventions revoked by the literary reform of Romanticism. A theater of Paris cabarets was to soon follow in its footsteps with the projects of great 19th century stage reformers - and this is not the only resemblance to the later cabaret art that could be found in this 1870 os newspaper theater.

KEYWORD S

cabaret, parody, Polish drama, Polish theater 